Pereira, J.C., Gorlach-Lira, K. \& de Veras, B.O. (2021). Antimicrobial activity of bacteria isolated from tissue of the coral Palythoa caribaeorum (Zoantharia: Sphenopidae) from Paraíba, Brazil coastal reefs. Revista de Biología Tropical, 69(2), 462-471. DOI 10.15517/rbt.v69i2.40809

DOI 10.15517/rbt.v69i2.40809

\title{
Antimicrobial activity of bacteria isolated from tissue of the coral Palythoa caribaeorum (Zoantharia: Sphenopidae) from Paraíba, Brazil coastal reefs
}

\author{
Jalcinês C. Pereira ${ }^{1}$ \\ Krystyna Gorlach-Lira ${ }^{2 *}$ \\ Bruno O. de Veras ${ }^{3}$
}

1. Federal University of Paraiba, Post-graduation Program in Cell and Molecular Biology, João Pessoa, Brazil; jalcinescosta@gmail.com

2. Federal University of Paraiba, Departament of Molecular Biology, João Pessoa, Brazil; kglira@yahoo.com

3. Federal University of Pernambuco, Post-graduation Program in Tropical Medicine, Recife, Brazil; brunooveras@hotmail.com; *Correspondence

Received 22-II-2020. Corrected 21-X-2020. Accepted 11-II-2021.

\begin{abstract}
Introduction: The coral-associated bacteria with antimicrobial activity may be important to promote the health of their host through various interactions, and may be explored as a source of new bioactive compounds. Objective: To analyze the antimicrobial activity of bacteria associated with the zoanthid Palythoa caribaeorum from the coral reefs of Carapibus, Paraiba state, Brazil. Methods: The phylogenetic analysis of the bacteria was conducted based on partial sequences of the 16S rRNA gene using molecular and bioinformatics tools. The antimicrobial activity of the 49 isolates was tested against four bacterial strains and one yeast strain: Bacillus cereus (CCT0198), Escherichia coli (ATCC 25922), Staphylococcus aureus (ATCC 25923), Pseudomonas aeruginosa and Candida albicans (ATCC 10231). The antibiosis and antibiogram assays were conducted and the Minimal Inhibitory Concentration (MIC) was determined by the microdilution method. Results: The bacterial isolates belonged to Firmicutes phylum ( $84 \%$ of the isolates) and the Proteobacteria phylum (16\% of the isolates). Among the 49 isolates five genera were found, with the Bacillus genus being the most abundant ( $82 \%$ of the isolates), followed by Vibrio (10\%), Pseudomonas (4\%), Staphylococcus (2\%) and Alteromonas (2\%). Antibiosis test revealed that 16 isolates $(33 \%)$ showed antimicrobial activity against one or more of five tested reference strains. The highest number of antagonistic bacteria were found in the Bacillus genus (12 isolates), followed by Vibrio (three isolates) and Pseudomonas (one isolate) genera. The B. subtilis NC8 was the only isolate that inhibited all tested strains in the antibiosis assay. However, antibiogram test with post-culture cell-free supernatant of NC8 isolate showed the inhibition of only B. cereus, S. aureus and C. albicans, and the lyophilized and dialyzed material of this isolate inhibited only $B$. cereus. The lyophilized material showed bacteriostatic activity against $B$. cereus, with a MIC value of $125 \mu \mathrm{g} / \mu \mathrm{l}$, and in the cytotoxicity assay, the hemolysis value was of 4.8 $\%$, indicating its low cytotoxicity. Conclusions: The results show the antimicrobial potential of some bacterial isolates associated with the $P$. caribaeourum tissue, especially those belonged to Bacillus genus.
\end{abstract}

Key words: antimicrobial substances; marine bacteria; Bacillus; zoanthid; Palythoa caribaeorum.

Reef environments are restricted to the tropical regions and they are spread over 3000 $\mathrm{km}$ along the coast in Brazil, showing high rate of endemic coral species (Francini-Filho et al.,
2013; Leão et al., 2016). Coral reefs are distributed in the state of Paraiba over the entire coastal stretch of $138 \mathrm{~km}$ (Costa, Sassi, Costa, $\&$ Brito, 2007). 
Palythoa caribaeorum is a species of typically sessile colonial zoanthid found frequently in coral reefs along the coast of the Atlantic Ocean and oceanic islands, being one of the most representative species of the several coral reefs of Brazil, Caribbean and Florida. Zoanthids, such as $P$. caribaeorum, may occupy large surface area of disturbed reefs since their high physiological tolerance and reproductive rates (Francini-Filho et al., 2013; Silva et al., 2015; Durante, Cruz, \& Lotufo, 2018).

In various regions of Northeastern Brazil, including the Paraiba coast, P. caribaeorum is one of the most abundant zoanthid in the reef environments (Costa, Sassi, Gorlach-Lira, Lajeunesse, \& Fitt, 2013; Melo, Lins, \& Eloy, 2014; Araújo, Gorlach-Lira, Medeiros, \& Sassi, 2015; Silva, 2015). The occupational success of this species is mainly due to competitive strategies and rapid growth, even in unfavorable conditions such as high sedimentation (Castro, Segal, Negrão, \& Calderon, 2012). The microbiota associated with P. caribaeorum is still little known. According to Pereira, Palermo, Carlos, \& Ottoboni (2017), the Alphaproteobacteria were abundant in the mucus of this species, while Silva (2015) revealed that the majority of bacterial isolates from $P$. caribaeorum tissue belonged to the Bacilli class of Firmicutes phylum, followed by the Gammaproteobacteria.

Recent works has demonstrated the importance of the bacterial community for the health, development and resilience of various species of corals and zoanthids (Pham, Wiese, Wenzel-Storjohann, \& Imhoff, 2016; Pereira et al., 2017). According to these studies, the antimicrobial activity performed by associated bacteria promotes the health of its host through ecological interactions, and may represent a source for obtaining new bioactive compounds, which can be used in the production of new drugs. Bacillus was found to be one of the leading genera with antimicrobial activity among bacteria associated with corals (Pham et al., 2016; Pereira et al., 2017). The bioactive compounds with antimicrobial properties of marine Bacillus species have been extensively reviewed by Mondol, Sin, \& Islam (2013).

Since several studies (Li et al., 2011; Li et al., 2012; Pereira et al., 2017; Mickymaray et al., 2018) show that bacteria associated with corals might be promissory producers of bioactive compounds, we aimed in this work to perform phylogenetic analysis and to analyze antimicrobial activity of bacteria isolated from the tissue of P. caribaeorum from the reefs of Carapibus, Paraiba state, Brazil.

\section{MATERIALS AND METHODS}

Bacterial isolates: The bacteria were isolated from healthy and necrotic tissue from the zoanthid Palythoa caribaeorum from the coastal reefs of Carapibus, Paraíba state, Brazil (7'17'59.14" S \& $34^{\circ} 47^{\prime} 45^{\prime}$ " W). The isolation procedure was described by Silva (2015).

DNA extraction and amplification: Bacterial isolates were incubated in Brain and Heart Infusion Broth (BHI) at $37{ }^{\circ} \mathrm{C}$ for 48 hours. The extraction of genomic DNA from bacterial isolates was performed using the KIT HiPura TM Miniprep (HiMedia), according to the manufacturer's instructions. The 16S rRNA gene was amplified in the thermocycler (Primus, USA) using the following universal primers (50 pmol): forward 26F: 5'- GAG TTT GAT CMT GGC TCA G - 3' and reverse 1492R: 5' - ACG GCT ACC TTG TTA CGA CTT - 3' (Lane, 1991), $200 \mathrm{ng}$ of genomic DNA and the Master Mix PCR kit (Promega), according to the manufacturer's instructions. The amplification and purification of the 16S rRNA were done as described by Silva (2015).

Phylogenetic sequencing and analysis: The sequencing of the samples was carried out at the Federal University of Pernambuco Sequencing Platform, Recife, Brazil, using the automatic sequencer ABI-PRISM 3100 Genetic Analyzer (Applied Biosystems). The generated sequences were submitted to a query for similarity with the data deposited in the GenBank accessed through the NCBI (National 
Center for Biotechnology Information) using the program BLAST-"Basic Local Alignment Search Tools" (Altschul et al., 1997). Sequences with more than $97 \%$ similarity were considered valid. The multiple alignment of the sequences and the construction of the phylogenetic tree were performed using the MEGA version 6 program (Tamura, Stecher, Peterson, Filipski, \& Kumar, 2013). The sequences of antagonistic isolates used to construct the phylogenetic tree were deposited in the NCBI sequence database (GenBank access numbers: MT071323-MT071338).

Antibiosis test: The antimicrobial activity of isolates was analyzed against the following standard strains: Escherichia coli (ATCC 25922), Pseudomonas aeruginosa, Bacillus cereus (CCT0198), Staphylococcus aureus (ATCC 25923) and Candida albicans (ATCC 10231). The isolates and standard strains were grown in the Brain and Heart Infusion Agar (HiMedia) at $37^{\circ} \mathrm{C}$ for 48 hours. The $B$. cereus was incubated for 24 hours due to its rapid formation of endospores. For the antibiosis test, the cross-streak method was used, where each tested isolate was inoculated in a central line of a Petri dish containing Mueller Hinton Agar and incubated for 48 hours at $37^{\circ} \mathrm{C}$. After this period, the standard strains were inoculated perpendicularly to the central streak culture. The cultures were analyzed after 24 hours of incubation in order to verify possible inhibition of the growth of standard strains.

Antibiogram test: The diffusion method in solid medium (antibiogram) on Mueller-Hinton Agar (HiMedia) was used to evaluate antimicrobial activity of the cell-free supernatant, lyophilized material and dialysate of the NC8 isolate against the five standard strains mentioned above. The NC8 isolate was grown in Marine Broth (sea water 11 , peptone $5 \mathrm{~g}$, yeast extract $2 \mathrm{~g}$ ) and Mueller Hinton Broth (HiMedia) at $37{ }^{\circ} \mathrm{C}$ for $48 \mathrm{~h}$, and after incubation a $1.5 \mathrm{ml}$ aliquot of the culture was centrifuged for 10 minutes at $12000 \mathrm{rpm}$. $50 \mu \mathrm{l}$ aliquots of cell-free supernatant were placed in the wells on Mueller Hinton Agar previously inoculated with standard strains. After the incubation period for 24 hours at $37{ }^{\circ} \mathrm{C}$, the diameter of the inhibition halo was measured. All analyzes were done in duplicate. An antibiogram test was also conducted using the lyophilized material $(1.0 \mathrm{~g} / \mathrm{ml})$ obtained after lyophilization process of $400 \mathrm{ml}$ of NC8 isolate supernatant The lyophilized material was also subjected to dialysis with a cellulose membrane with a flat width of $10 \mathrm{~mm}$ and $6 \mathrm{~mm}$ in diameter (Sigma), that retain most proteins of molecular weight 12000 or greater, obtaining the material with concentration of $0.01 \mathrm{~g} / \mathrm{ml}$.

\section{Determination of Minimum Inhibitory} Concentration (MIC): The antimicrobial susceptibility test performed for the NC8 isolate was based on the reference method for broth microdilution tests for aerobic growth bacteria (M27-A6) (NCCLS, 2003). The MIC of the lyophilized material of the NC8 isolate was determined against the standard strain B. cereus in a 96-well microplate, using $\mathrm{BHI}$ broth and nine dilutions $(1.95-500 \mu \mathrm{g} / \mu \mathrm{l})$ of the lyophilized material. Each well received $10 \mu \mathrm{l}\left(3 \times 10^{8} \mathrm{CFU} / \mathrm{ml}\right)$ of the standard strain cell suspension of $B$. cereus. The aliquots of 10 $\mu \mathrm{l}$ of antibiotic streptomycin sulfate $(0.1 \mathrm{~g} / \mathrm{ml})$ was used as a control for the relative evaluation of the level of inhibition of the tested samples. Controls were also carried out for the viability of the tested microorganism and the sterility of the culture medium. The test was performed in triplicate. The microplates were incubated at 37 ${ }^{\circ} \mathrm{C}$ in the Thermo Scientific ${ }^{\mathrm{TM}}$ Multiskan ${ }^{\mathrm{TM}} \mathrm{GO}$ Microplate Spectrophotometer and the optical density measurements $(540 \mathrm{~nm})$ were recorded every 1 hour during 24 hours of incubation. The Minimum Bactericidal Concentration (MBC) was determined using $10 \mu \mathrm{l}$ aliquots collected from each CIM assay well and inoculated on Mueller-Hinton agar medium. After incubation at $37{ }^{\circ} \mathrm{C}$ for 24 hours the growth of bacterial colonies was observed. The CBM value was considered as the lowest concentration of lyophilized material in which microbial growth was not detected. 
Hemolysis test: Hemolytic activity was measured by determining human erythrocyte lysis (hRBCs), provided by the hospital of the Federal University of Rio Grande do Norte, Natal, Brazil. Hemolytic activity was tested by incubating the material subjected to lyophilization and dialysis $(0.01 \mathrm{~g} / \mathrm{ml})$ with erythrocytes at $2 \%$ of the $\mathrm{O}$ - group washed three times with PBS (phosphate buffered saline), pH 7.2. Saline solution $(\mathrm{NaCl} 0.9 \%)$ was used as a negative control and Triton X-100 (1\%) as a positive control. The samples were incubated for 4.8 and $12 \mathrm{~h}$ at $37^{\circ} \mathrm{C}$ and then centrifuged at $2500 \mathrm{rpm}$ for $5 \mathrm{~min}$. Hemolysis was measured by spectrophotometry at a wavelength of $540 \mathrm{~nm}$ in 96 wells microplate, using $200 \mu \mathrm{l}$ of samples. All tests were performed in triplicate and expressed as a percentage (Ahmad, Khan, Manzoor, \& Khan, 2010).

\section{RESULTS}

Phylogenetic analysis of bacteria: The bacterial isolates obtained from healthy (19 isolates) and necrotic tissue (30 isolates) of the zoanthid $P$. caribaeorum were identified on the basis of partial sequences of 16S rRNA. The isolates showed $98-100 \%$ similarity with the sequences deposited in the GenBank and belonged to the phyla: Firmicutes with $84 \%$ and Proteobacteria with $16 \%$ of the isolates
(Table 1). The Firmicutes phylum was represented by two families, Bacillaceae and Staphylococcaceae, distributed in Bacillus and Staphylococcus genera, respectively (Table 1). The isolates of Proteobacteria phylum belonged to the families of Pseudomonadaceae, Vibrionaceae and Alteromonadaceae, distributed in genera of Pseudomonas, Vibrio and Alteromonas, respectively (Table 1).

Antibiosis: The antibiosis test revealed that among 49 tested isolates, 16 (33\%) exhibited antagonistic activity against at least one of the five standard strains tested (Fig. 1). Among the healthy tissue isolates, only two (Bacillus sp. PS1, Vibrio sp. PS11) showed antagonistic activity, while 14 isolates from the necrotic tissue were positive in this test, with 11 isolates belonging to the Bacillus genus, 2 to the Vibrio genus and 1 to the Pseudomonas genus.

Among antagonistic isolates, the Vibrio isolates (PS11, PN13, PN35) showed similarity with the species of $V$. harveyi and $V$. campbellii (Table 1, Fig. 1) and Bacillus isolates were phylogenetically related to $B$. zhangzhouensis, B. pumilus and B. safensis (PN29, PN70, PN71, PN73, PN78, PN85, PN89, PN91, PN92, PN94), one to B. aerius (PS1) and one to B. subtilis (NC8) (Table 1, Fig. 1).

Among the tested microorganisms, C. albicans and E. coli were more sensitive to the

TABLE 1

Classification of bacterial isolates from the tissue of $P$. caribaeorum based on partial sequences of $16 \mathrm{~S}$ rRNA. The E values were 0.0 and the maximal identity $98-100 \%$

\section{Phylum/Family/Genus/Species}

Firmicutes/Bacillaceae/Bacillus/B. aerius (NR 118439.1)

B. zhangzhouensis (NR 148786.1)

B. subtilis (NR 04324.1)

B. pumilus (NR 113945.1)

Firmicutes/Staphylococcaceae/Staphylococcus/S. epidermidis (NR 113957.1)

Proteobacteria/Pseudomonadaceae/Pseudomonas/P. stutzeri (NR 103934.2)

Proteobacteria/Vibrionaceae/Vibrio/V. campbellii (NR 119050.1) and V. harveyi (NR 102976.1)

V. proetolyticus (NR118095.1)

Proteobacteria/Alteromonadaceae/Alteromonas/A. macleodii (NR 074797.1)

Total
Number of Isolates

19

10

1

10

1

2

4

1

1

49

NNR: GenBank access code. 


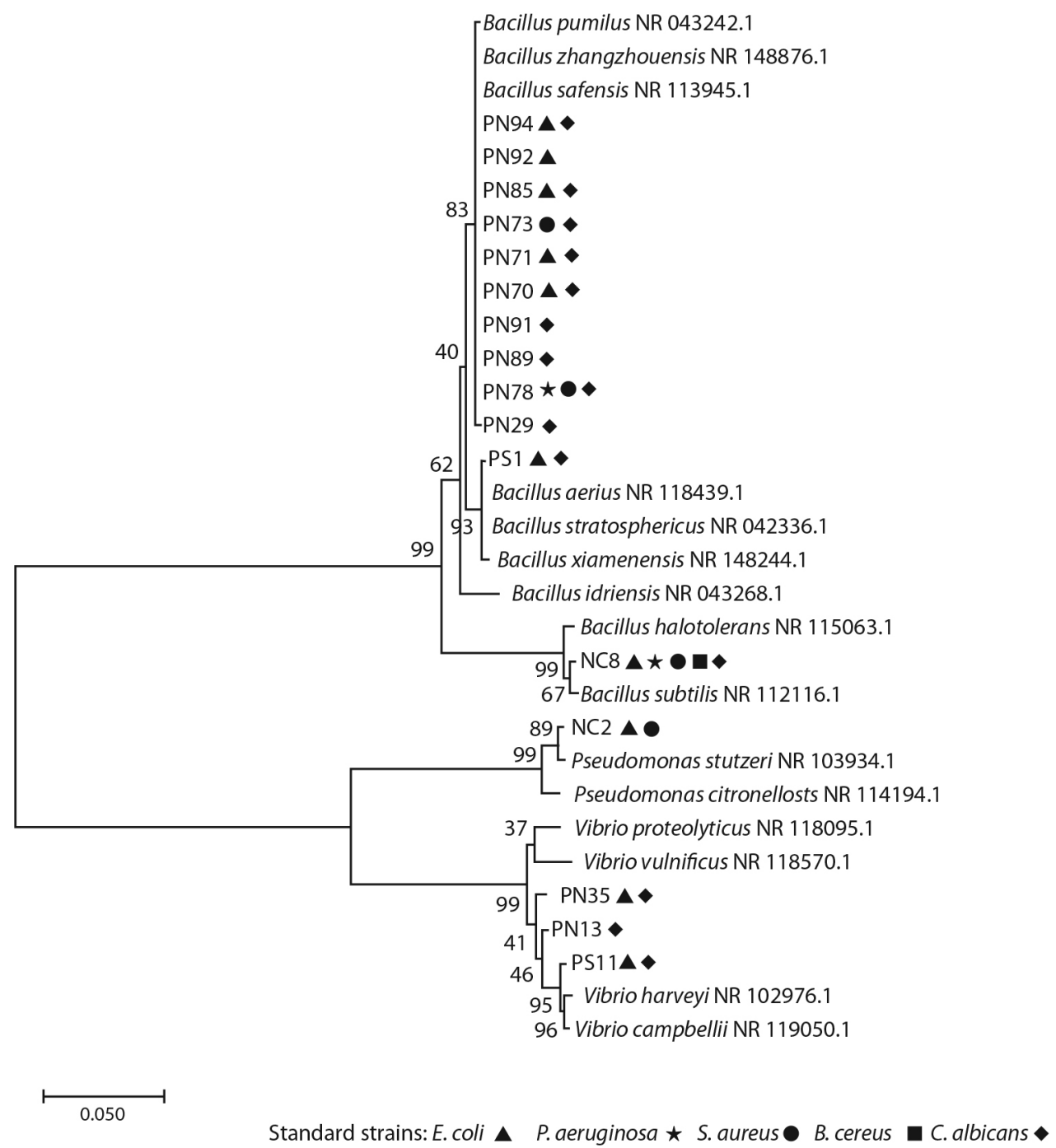

Fig. 1. Phylogenetic tree of antagonistic bacteria isolated from the healthy and necrotic tissue of Palythoa caribaeorum and from bacterial strains of the GenBank based on the comparison of the sequences of RNAr 16S using neighbor-joining analysis and the Tamura 3-parameter model. The bootstrap values shown in the tree were obtained based on 1000 replicates. Access numbers for GenBank strains are shown in parentheses.

antimicrobial action of most isolates. C. albicans growth was inhibited by 13 isolates, and among them 10 isolates were Bacillus spp. and three isolates Vibrio spp. The E. coli growth was inhibited by seven isolates of Bacillus spp., two of Vibrio spp. and one isolate of Pseudomonas sp. Among these antagonistic isolates, eight were obtained from necrotic and two from healthy tissue of $P$. caribaeorum.

The growth of $S$. aureus was inhibited by four Bacillus isolates of the necrotic tissue of the zoanthid, and $P$. aeruginosa growth was weakly inhibited by two isolates of Bacillus spp. The B. cereus was inhibited only by 
TABLE 2

Antibiogram test of cell-free supernatant and lyophilized and dialyzed material from $B$. subtilis NC8 isolate

\begin{tabular}{|c|c|c|c|c|c|}
\hline \multirow{2}{*}{ Material } & E. coli & P. aeruginosa & S. aureus & B. cereus & C. albicans \\
\hline & \multicolumn{5}{|c|}{ Inhibition zone (mm) } \\
\hline Post-culture liquid & - & - & $11.00(\mathrm{MHB})^{1}$ & $13.5(\mathrm{MB})^{2}$ & 20.5 (MHB) \\
\hline Lyophilized material & - & - & - & $14.6(\mathrm{MB})^{2}$ & - \\
\hline Dialyzed material & - & - & - & $13.3(\mathrm{MB})^{2}$ & - \\
\hline
\end{tabular}

1. MHB-Mueller Hinton Broth; ${ }^{2} \mathrm{MB}-$ Marine Broth.

the isolate Bacillus subtilis NC8. Among the bacterial isolates tested in the antibiosis assay, the NC8 isolate was the only one that showed growth inhibition of all standard strains in the antibiosis test.

\section{Antimicrobial activity of Bacillus subti-}

lis NC8: The cell-free supernatant of the NC8 isolate showed antimicrobial action against standard strains of $B$. cereus, $S$. aureus and $C$. albicans (Table 2). However, the activity of the lyophilized material $(1.0 \mathrm{~g} / \mathrm{ml})$ and material subjected to dialysis $(0.01 \mathrm{~g} / \mathrm{ml})$ showed antibacterial activity in the antibiogram test only against $B$. cereus, with no antimicrobial action against other standard strains. Therefore, the tests to determine the MIC and MBC were conducted only against the strain of $B$. cereus using lyophilized material.

On the basis of the microdilution test, the MIC value of lyophilized material was $125 \mu \mathrm{g} /$ $\mu \mathrm{l}$ (Fig. 2). The optical density values $(540 \mathrm{~nm})$ revealed that the $B$. cereus did not show growth during 24 hours of the test in the presence of $500.0 \mu \mathrm{g} / \mu \mathrm{l}, 250.0 \mu \mathrm{g} / \mu \mathrm{l}$ and $125.0 \mu \mathrm{g} / \mu \mathrm{l}$ lyophilized material (OD $540 \mathrm{~nm}$ : 0.09) (Fig. 2). Concentrations of $62.5 \mu \mathrm{g} / \mu \mathrm{l}, 31.25$ and $15.63 \mu \mathrm{g} / \mu \mathrm{l}$ inhibited the growth of $B$. cereus up to 6 hours of incubation, and after this period the growth of the isolate was detected

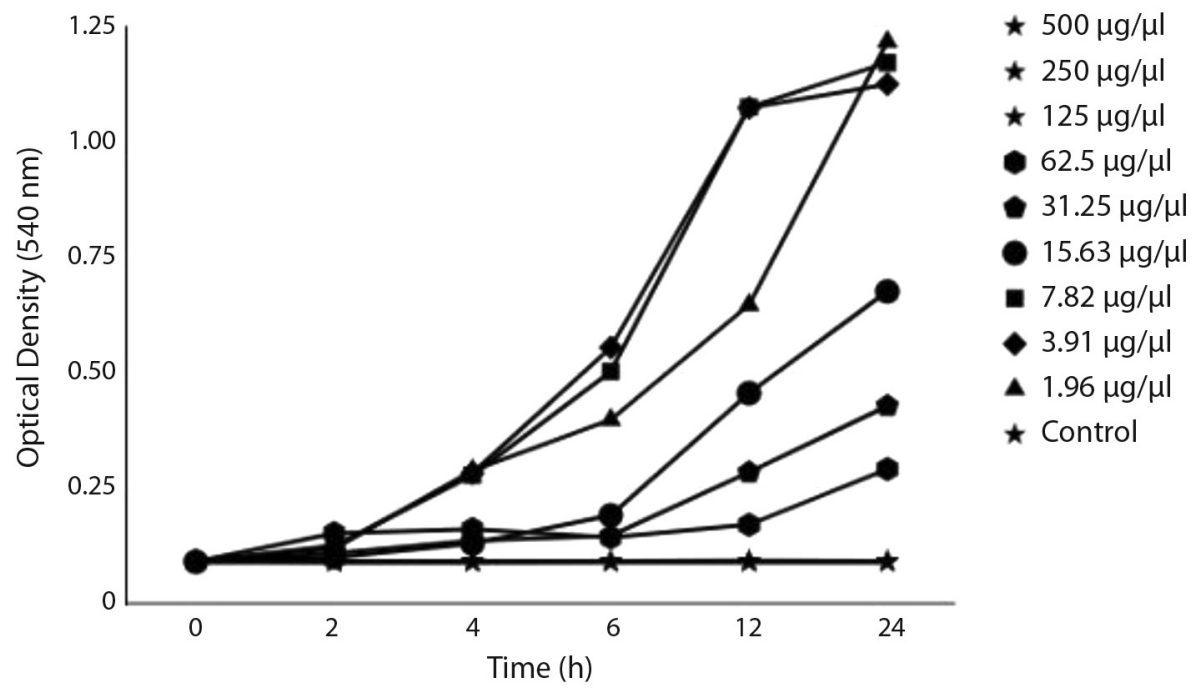

Fig. 2. Growth kinetics of standard strain of B. cereus in the presence of lyophilized material $(1.96-500 \mu \mathrm{g} / \mathrm{ml})$ of the B. subtilis NC8 isolate in the microdilution test. The growth was measured by spectrophotometry at $540 \mathrm{~nm}$ in 96 wells microplate during 24 hours of incubation. Control-the culture medium without the addition of lyophilized material. 


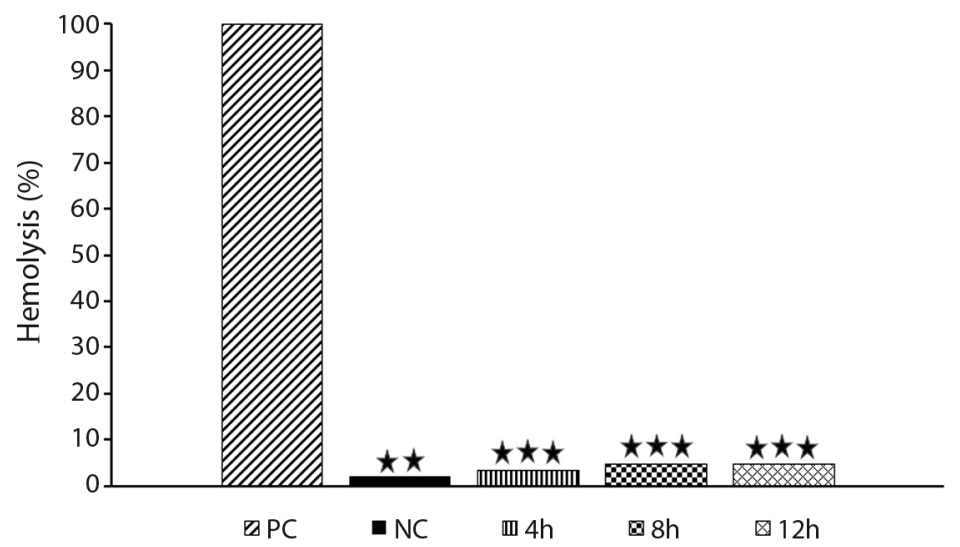

Fig. 3. Hemolytic activity of the material subjected to lyophilization and dialysis $(0.01 \mathrm{~g} / \mathrm{ml})$ obtained from isolate $B$. subtilis NC8. Hemolysis of erythrocytes at $2 \%$ of the O- group was measured by spectrophotometry at $540 \mathrm{~nm}$ in 96 wells microplate after 4.8 and 12 hours of incubation. Positive control- $1 \%$ of Triton X-100; negative control- $0.9 \%$ of $\mathrm{NaCl}$.

(OD 540 nm: 0.14-0.19). Concentrations below $15.63 \mu \mathrm{g} / \mu \mathrm{l}$ lyophilized material did not reduce the growth of $B$. cereus.

The result of the MBC test showed the microbial growth in all concentrations of lyophilized material $(500 \mu \mathrm{g} / \mu \mathrm{l}-1.96 \mu \mathrm{g} / \mu \mathrm{l})$ tested, demonstrating that the antimicrobial activity of the lyophilized material of NC8 isolate had bacteriostatic activity.

The hemolytic rate of the lyophilized material subjected to dialysis was $4.8 \%$ in the concentration of $0.01 \mathrm{mg} / \mathrm{ml}$ during the 12 hours of incubation (Fig. 3). Hemolysis obtained by Triton X-100 (1\%) (positive control) was considered $100 \%$ hemolysis.

\section{DISCUSSION}

In the coastal reefs of Carapibus Beach of Conde (Paraiba state, Brazil), the colonies of $P$. caribaeorum are wide spread and some colonies are affected by a tissue necrosis (Silva, 2015). Among the bacteria associated with the tissue of $P$. caribaeorum the Bacillus genus was the most abundant ( $84 \%$ of the isolates), followed by genera of Vibrio, Pseudomonas, Staphylococcus and Alteromonas.

When studying the biodiversity of bacteria associated with the soft coral Alcionium digitatum, abundant in the Baltic Sea, Pham et al. (2016) also identified the genus Bacillus as the most abundant and diverse group, with 17 species. The genus Bacillus was also found in other species of corals, however, in smaller proportions in relation to other taxa found. For example, Eiahwany, Ghozlan, Eisharif, \& Sabry (2013) found that bacteria associated with soft coral Sarcophyton glaucum the Red Sea reefs were representatives of the Gammaproteobacteria, Actinobacteria and Firmicutes, and 11 species of Bacillus were found. The authors reported a high proportion of bacteria with antimicrobial and antifungal activities, especially those belonging to the Bacillus genus that showed higher antimicrobial activity. They suggested that these bacteria may play an important protective role, helping their host in the defense against marine pathogens.

In our study, the class of gram-negative bacteria Gammaproteobacteria was found in a smaller proportion (16\%), however, other works has reported that Gammaproteobacteria dominate the microbial community, although there is a variation of genera associated with zoanthids and corals (Moreira et al., 2014; Pereira et al., 2017).

In our study, some isolates, mostly from the necrotic tissue of $P$. caribaeorum, were phylogenetically related to such as V. campbellii, known to be a pathogen of aquatic 
organisms. Among the isolates were also found Staphylococcus epidermidis, disease-causing species in humans, and P. stutzeri, considered an opportunistic pathogen in clinical settings.

Potentially pathogenic bacteria for humans have also been found in the microbiota of $P$. caribaeorum on the coral reef of Ponta Verde in Maceio, Alagoa state, Brazil, exposed to untreated sewage dumping (Paulino, 2017). This work reported changes in the microbial community associated with $P$. caribaeorum due to anthropogenic effect, studied, showing that about $25 \%$ of sequences obtained by pyrosequencing techniques belonged to the Streptococcus, Staphylococcus and Propionibacterium genera.

The antimicrobial activity was evidenced in $33 \%$ of the tested bacterial isolates, and higher number of antagonistic bacteria was obtained from the necrotic tissue of $P$. caribaeorum. The genus Bacillus presented a greater number of isolates with antimicrobial activity, and among them the B. subtilis NC8 was the only one that inhibited the growth of the five standard strains in antibiosis test. The hemolysis assay of the lyophilized and dialyzed material of the NC8 isolate was less than $5 \%$, indicating that the antimicrobial compounds has probably no cytotoxic activity, that is very important characteristic for the potential use of this isolate for the production of antimicrobials.

Several studies report that marine Bacillus species with potential action and broad antimicrobial spectrum were isolated from several species of corals (Pham et al., 2016; Pereira et al., 2017).

Li et al. (2011) studied the bogorol A, a new peptide antibiotic produced by $B$. subtilis isolated from a reef in Papua, New Guinea, and found its high activity against methicillinresistant $S$. aureus (MRSA), vancomycin resistant enterococcus (VRE) and E. coli. In a later study, Li et al. (2012) reported that the amide group $\mathrm{C}-12$ amikoumarkin produced by marine bacterium $B$. subtilis from the Red Sea exhibited antimicrobial activity against $B$. subtilis, $S$. aureus and Laribacter hongkongensis.
Various species of Bacillus produce bacteriocins, for example Bacillus sp. SM01, isolated from mangrove sediments which produced bacteriocin Bac-SM01 with long-range antimicrobial activity, strongly inhibiting the growth of $S$. aureus methicillin resistant (MRSA), Acinetobacter baumannii, P. aeruginosa and E. coli (Mickymaray et al., 2018).

Antimicrobial compounds are promising sources for the production of new drugs and can be used to fight infectious diseases. In our study various marine isolates showed antimicrobial activity against a range of pathogenic microorganisms, and particularly one isolate B. subtilis $\mathrm{NC} 8$, that show a potential to be explored in the future studies.

\section{ACKNOWLEDGMENTS}

We thank Coordination for the Improvement of Higher Education Personnel (CAPES) for the scholarship granted to Jalcinês da Costa Pereira. We acknowledge the Cell and Molecular Biology Post-Graduate Program of the Federal University of Paraiba for institutional support and Laboratory of Reef Environments and Biotechnology of Microalgae (LARBIM) of the Federal University of Paraiba for technical support.

\section{RESUMEN}

Actividad antimicrobiana de bacterias aisladas del tejido del coral Palythoa caribaeorum (Zoantharia: Sphenopidae) de los arrecifes costeros de Paraíba, Brasil. Introducción: La actividad antimicrobiana realizada por las bacterias asociadas con los corales, además de promover la salud de su huésped, representa una fuente para obtener nuevos compuestos bioactivos. Objetivo: Analizar la actividad antimicrobiana de las bacterias asociadas con el zoantario Palythoa caribaeorum de los arrecifes de Carapibus, Paraíba, Brasil. Metodología: El análisis filogenético de la bacterias se realizó con base en secuencias parciales del gen RNAr 16S utilizando herramientas moleculares y de bioinformática. La actividad antimicrobiana de las cepas se probó contra cuatro cepas bacterianas y una cepa de levadura: Bacillus cereus (CCT0198), Escherichia coli (ATCC 25922), Staphylococcus aureus (ATCC 25923), Pseudomonas aeruginosa y Candida albicans (ATCC 10231), utilizando ensayos antibiosis y antibiograma, y la concentración inhibitoria mínima (CIM) que se determinó 
por el método de microdilución. Resultados: Las cepas bacterianas pertenecían a Firmicutes (84\%) y Gammaproteobacteria (16\%). Entre 49 cepas se encontraron cinco géneros de bacterias: Bacillus, Vibrio, Pseudomonas, Staphylococcus y Alteromonas. Un total de 19 cepas exhibieron actividad antimicrobiana, siendo el género Bacillus el responsable del mayor número de bacterias antagonistas, con 12 cepas positivas en el ensayo de antibiosis y cuatro en la prueba de antibiograma. El mayor número de bacterias antagonistas se encontró en Bacillus (12 aislamientos), seguido por Vibrio (tres aislamientos) y Pseudomonas (un aisladmiento). El NC8, clasificado como Bacillus subtilis, inhibió todas las cepas estándar en el ensayo de antibiosis y las cepas de $B$. cereus, $S$. aureus y $C$. albicans en la prueba de antibiograma. El material liofilizado del $B$. subtilis NC8 mostró acción bacteriostática contra $B$. cereus, con un valor de CIM de $125 \mu \mathrm{g} / \mu \mathrm{l}$. En la prueba de citotoxicidad, el grado de hemólisis fue del $4.8 \%$ para el material liofilizado a las concentraciones probadas, lo que indica su baja citotoxicidad. Conclusión: Los resultados muestran el potencial antimicrobiano de algunos aislamientos bacterianos asociados al P. caribaeourum, especialmente los pertenecientes al género Bacillus.

Palabras clave: sustancias antimicrobianas; bacterias marinas; Bacillus; zoantario; Palythoa caribaeorum.

\section{REFERENCES}

Ahamad, A., Khan, A., Manzoor, N., \& Khan, L.A. (2010). Evolution of ergosterol biosynthesis inhibitors as fungicidal against Candida. Microbial Pathogenesis, 48, 35-41. DOI: 10.1016 / j.micpath.2009.10.001

Altschul, S.F., Madden, T.L., Schaffer, A.A., Zhang, J., Zhang, Z., Miller, W., \& David, J.L. (1997). Gapped BLAST and PSI-BLAST: a new generation of protein database search programs. Nucleic Acids Research, 25, 3389-3402. DOI: 10.1093/nar/25.17.3389

Araújo, G.H., Gorlach-Lira, K., Medeiros, D.S., \& Sassi, C.F.C. (2015). Physicochemical and bacteriological seawater quality and sustainability of Cabo Branco (Brazil) coral reef. Pan-American Journal of Aquatic Sciences, 10(2), 94-104.

Castro, C.B., Segal, B., Negrão, F., \& Calderon, E.N. (2012). Four-year monthly sediment deposition on turbid Southwestern Atlantic coral reefs, with a comparison of benthic assemblages. Brazilian Journal of Oceanography, 60(1), 49-63. DOI: 10.1590/ S1679-87592012000100006

Costa, C.F., Sassi, R., Costa, M.A.J., \& Brito, A.C.L. (2007). Recifes costeiros da Paraíba, Brasil: usos, impactos e necessidades de manejo no contexto da sustentabilidade. Gaia Scientia, 1(1), 37-45. Retrieved from https://periodicos.ufpb.br/ojs/index.php/ gaia/article/view/2226
Costa. C.F., Sassi, R., Gorlach-Lira, K., Lajeunesse, T.C., \& Fitt, W.K. (2013). Seasonal changes in zooxanthellae harbored by zoanthids (Cnidaria, Zoanthidea) from coastal reefs in Northeastern Brazil. PanAmerican Journal of Aquatic Sciences, 8(4), 253-264.

Durante, L.M., Cruz, I.C.S., \& Lotufo, T.M.C. (2018). The effect of climate change on the distribution of a tropical zoanthid (Palythoa caribaeorum) and its ecological implications. Peer J-the journal of live and Environmental Sciences, 6, e4777. DOI: 10.7717/ peerj. 4777

Eiahwany, A.M.D., Ghozlan, H.A., Eisharif, H.A., \& Sabry, S.A. (2013) Phylogenetic diversity and antimicrobial activity of marine bacteria associated with the soft coral Sarcophytonglaucum. Journal of Basic Microbiology, 55(1), 2-10. DOI: 10.1002/jobm.201300195

Francini-Filho, R.B., Coni, E.O.C., Meirelles, P.M., Amado-Filho, G.M., Thompson, F.L., Pereira-Filho, G.H., .. Moura, R. (2013). Dynamics of coral reef benthic assemblages of the Abrolhos bank, eastern Brazil: inferences on natural end anthropogenic drivers. Plos One, 8(1), e54260. DOI: 10.1371/journal. pone. 0054260

Lane, D.J. (1991). 16S/23S rRNA sequencing. In E. Stackebrandt \& M. Goodfellow (Eds.), Nucleic acid techniques in bacterial systematics (pp. 115-175). New York, USA: John Wiley \& Sons, Inc.

Leão, Z.M.A.N., Kikuchi, R.K.P., Ferreira, B.P., Neves, E.G., Sovierzoski, H.H., Oliveira, M.D.M., ... Johnson, R. (2016). Brazilian coral reefs in a period of global change: A synthesis. Brazilian Journal of Oceanography, 64(sp2), 97-116. DOI: 10.1590/ S1679-875920160916064sp2

Li, D., Carr, G., Zang, Y., Williams, D.E., Amlani, A., Bottriell, H., ... Andersen, R. (2011). Turnagainolides $\mathrm{A}$ and $\mathrm{B}$, cyclic depsipeptides produced in culture by a Bacillus sp.: isolation, structure elucidation, and synthesis. Journal of Natural Products, 74(5), 10931099. DOI: $10.1021 / \mathrm{np} 200033 \mathrm{y}$

Li, Y., Xu, I., Liu, L., Han, Z., Lai, P.Y., Guo, X., ... Pei-Yuan, Q. (2012). Five new amicoumacins isolated from a marine-derive bacterium Bacillus subtilis. Marine Drugs, 10(2), 319-328. DOI:10.3390/ md10020319

Melo, R.S., Lins, R.P.M., \& Eloy, C.C. (2014). O Impacto do turismo em ambientes recifais: caso praia SeixasPenha, Paraíba, Brasil. REDE - Revista Eletrônica do Prodema, 8(1), 67-83.

Moreira, A.P.B., Luciane, A., Tonon, C., Pereira, C.V.P., Alves, N., Amado-Filho, G.M., ... Thompson, F.L. (2014). Culturable heterotrophic bacteria associated with healthy and bleached scleractinian Madracis decactis and the fireworm Hermodice carunculata from the remote St. Peter and St. Paul Archipelago, 
Brazil. Current Microbiology, 68(1), 38-46. DOI: 10.1007/s00284-013-0435-1

Mickymaray, S., Alturaiki, W., Al-Aboody, M.S., Mariappan, P., Rajenderan, V., Alsagaby, S.A., ... Alarfajj, A.A. (2018). Anti-bacterial efficacy of bacteriocin produced by marine Bacillus subtilis against clinically important extended spectrum beta-lactamase strains and methicillin-resistant Staphylococcus aureus. International Journal of Medical Research \& Health Sciences, 7(2), 75-83.

Mondol, M.A.M., Sin, H.J., \& Islam, M.T. (2013). Diversity of secondary metabolites from marine Bacillus species: chemistry and biological activity. Marine Drugs, 11(8), 2846-2872. DOI: 10.3390/md11082846

NCCLS. (2003). Methods for dilution antimicrobial susceptibility tests for bacteria that grow aerobically. Approved standard (Sixth Edition). Pensylvania, USA: NCCLS.

Paulino, G.V.B. (2017). Diversidade de bactérias nãocultiváveis associadas ao zoantídeo Palythoa caribaeorum (Dissertação de Mestrado). Universidade Federal de Alagoas, Maceió, Brasil. Retrieved from http://www.repositorio.ufal.br/handle/riufal/5412

Pereira, L.B., Palermo, B.R.Z., Carlos, C., \& Ottoboni, L.M.M. (2017). Diversity and antimicrobial activity of bacteria isolated from different Brazilian coral species. FEMS Microbiology Letters, 364(16). DOI: $10.1093 /$ femsle/fnx164

Pham, T.M., Wiese, J., Wenzel-Storjoann, A., \& Imhoff, J.F. (2016). Diversity and antimicrobial potential of bacterial isolates associated with the soft coral Alcyonium digitatum from the Baltic sea. Antonie Van Leeuwenhoek, 109(1), 105-119. DOI: 10.1007/ s10482-015-0613-1

Silva, R.M.S. (2015). Diversidade de bactérias cultiváveis associadas ás colonias sadias e necrosadas do zoantídeo Palythoa caribaeorum (Cnidaria, Anthozoa) dos recifes costeiros de Carapibus, Paraiba (Dissertação de Mestrado). Universidade Federal da Paraíba, João Pessoa, Brasil. Retrieved from https:// repositorio.ufpb.br/jspui/handle/tede/9442

Silva, J.F., Gomes, P.B., Santana, E.C., Silva, J.M., Lima, E.P., Santos, A.M.M., \& Pérez, C.D. (2015). Growth of the tropical zoanthid Palythoa caribaeorum (Cnidaria: Anthozoa) on reefs in Northeastern Brazil. Brazilian Academy of Sciences, 87(2), 985-996. DOI: 10.1590/0001-3765201520140475

Tamura, K., Stecher, G., Peterson, D., Filipski, A., \& Kumar, S. (2013). MEGA6: Molecular evolutionary genetics analysis version 6.0. Molecular Biology and Evolution, 30(12), 2725-2729. DOI: 10.1093/molbev/ mst197 